\title{
The Effects of Mobile Application in Teaching High School Mathematics
}

\author{
Jonathan O. Etcuban ${ }^{1 *}$, Leocineza D. Pantinople ${ }^{2}$ \\ ${ }^{1}$ University of Cebu, Cebu City, PHILIPPINES \\ ${ }^{2}$ Talamban National High School, Cebu City, PHILIPPINES \\ *CORRESPONDENCE: $₫$ joetcuban@gmail.com
}

\begin{abstract}
Mobile technology opens a new avenue for teaching and learning mathematics in schools in the $21^{\text {st }}$ century. This study determined the effects of using a mobile application in teaching mathematics among Grade 8 students of a public national high school, Cebu City, Philippines. The researchers used the quasi-experimental method of research using the pretest-posttest design. It used two groups of subjects with 40 students per group. The students were enrolled in Grade 8 mathematics. Frequencies, simple percentage, mean, standard deviation, rank, and t-test were used to treat the gathered data. The study revealed that there is an increase in the posttest scores of the control and experimental groups. It was concluded that the use of the mobile application in teaching mathematics to Grade 8 students had helped enhance students' achievement and learning. The researchers recommend that the proposed action plan be used and monitored to help students in mathematics.
\end{abstract}

Keywords: effectiveness, linear equations, mathematics, mobile app

\section{INTRODUCTION}

The primary focus of appropriate teaching is to bring about a desirable change in the behavior of learning. It is brought about by the teacher using teaching strategies to achieve the objectives of the lesson. This makes teaching more difficult yet very challenging because it requires different methods and techniques for different learner abilities and behavior.

As a science, teaching also requires knowledge of scientific discoveries regarding the teaching-learning process, the objectives of the lesson, subject matter and the nature of learners (Angeli \& Valanides, 2009; Niess, 2005). Teachers who believe in this point of view consider knowledge and applications of techniques already tested to bring about learning as a vital tool in their success as teachers (Stigler \& Hiebert, 2009; Sadik, 2008).

According to Etcuban (2013) that teachers are at the forefront of every learning institution. They teach and nurture the minds of students. Proserpio and Gioia (20007) added that teachers are responsible for understanding the needs, interest, and capabilities of the students so that they may intelligently provide for these needs most economically and practically. Furthermore, Sung et al. (2016) say that teachers must choose a teaching device for students to achieve well in class such as using mobile apps in teaching mathematics.

In the fields of teaching and learning, to be dominant is essential, in any case, to guarantee that both the substance of one is instructing and its style of introduction are reasonably coordinated to the requirements and interests and capacities of the people being educated. This requires a comprehensively based - innovative

\footnotetext{
Article History: Received 15 July 2018 • Revised 12 September $2018 \bullet$ Accepted 22 September 2018

(C) 2018 The Author(s). Open Access terms of the Creative Commons Attribution 4.0 International License (http://creativecommons.org/licenses/by/4.0/) apply. The license permits unrestricted use, distribution, and reproduction in any medium, on the condition that users give exact credit to the original author(s) and the source, provide a link to the Creative Commons license, and indicate if they made any changes.
} 
approach in which careful consideration is paid to the social and mental conditions under which instructing and learning happen.

Versatile innovation assumes a necessary part in the field of instruction (Sha et al., 2012). Students can easily access the whole world of information with mobile apps (Khaddage et al., 2011; Caudill, 2007). No need for them to carry loads of books to school and is environmentally friendly as well. It is an accepted fact that children these days are very much comfortable with electronic gadgets and equipment and the need to use these gadgets and equipment in teaching is highly evident. Children learn quickly through games and sporting activities; iPhone and Android apps are the way to go these days.

The researchers have observed students' low level of achievement in Mathematics. These students performed better on rote learning and poorly on items that require comprehension, and problem-solving skills. With this in mind, the researchers would like to investigate whether a mobile application is of great help in teaching mathematics to Grade 8 students from a public national high school. Also, this could be an instructional tool in the teaching of Linear Equations for a better teaching-learning experience that could be utilized by all types of learners.

\section{FRAMEWORK}

This study is based on the Anchored Instruction of John Bransford (1990). Anchored instruction is technology-based learning that has been developed by the Cognition \& Technology Group at Vanderbilt (CTGV) under the leadership of John Bransford. The theory focused on the development of interactive videodisc tools that encouraged students and teachers to pose and solve complex, realistic problems (HmeloSilver, 2004; Shyu, 2000). The video materials serve as anchors for all subsequent learning and instruction (Brown, 2006; Kritzenberger, 2004). The design of these anchors was entirely different from the design of videos that were typically used in education (Phillips et al., 2005; McNeese et al., 2002). It was to create exciting, realistic contexts that encouraged the active construction of knowledge by learners (Tan, 2003). The use of interactive videodisc technology makes it possible for students to easily explore the content and provide realistic roles to enhance the learning process (Naismith et al., 2004).

The Cognitive and Technology Group at Vanderbilt (CTGV) has developed a set of interactive videodisc programs called 'Jasper Woodbury Problem Solving Series. This program involves adventures in which mathematical concepts are used to solve problems (Dede, 2008).

Learning occurs in a pro-social but informal setting (Hromek \& Roffey, 2009). This suggests that learning takes place through social relationships, within a cultural milieu and by connecting prior knowledge to the new context (Bonk \& King, 2012). Barab and Plucker (2002) argue that learning is situated and embedded within activity, context, and culture. It is also usually unintentional rather than deliberate. Zhao and Kuh (2004) enunciated that students are more inclined to learn by actively participating in the learning experience. For learners, the mobile app is beneficial to learn from essential to advanced topics of any topics (Mouza \& Barrett-Greenly, 2015). According to Ally (2009) that the use of the mobile app for teaching and learning reduces paper usage. Thus, it is cost effective as well.

Franklin and Peng (2008) directed an instance of concentrate in which iPod Touch was utilized to help center school understudies find out about mathematical conditions and, precisely, the idea of slant, supreme esteem, and disposal. The improvement of math motion pictures for use on the iPod Touch gave understudies free methods for casual math learning past the long stretches of the classroom. While the investigation investigated the utilization of cell phones in an eighth-grade math classroom, the exercises learned are priceless to those looking to actualize portable innovations to help to instruct and learning with standard programming, for example, iMovie, PowerPoint, and iTunes.

Educators who endeavor to utilize request based, understudy focused instructional errands confront challenges that go past distinguishing all around composed undertakings and setting them up suitably in the classroom (Stein et al., 2008). They likewise included that educators must not just endeavor to see how understudies are comprehending the errand yet also start to adjust understudies' different thoughts and ways to deal with accepted understandings about the idea of arithmetic.

A variety of media can perform most instructional functions. Teachers, printed materials, films, mobile phone, and even computers may do equally well at explaining, illustrating or testing student's knowledge of a phenomenon, a concept or a rule (Rosen, 2010). Electronic media has become not merely tools, but the building blocks to a more efficient and exciting environment (Prahalad \& Ramaswamy, 2003). 
Johnson et al. (2016) found out that learning programs that use web-based teaching offer, students, more adaptability to learn at their own pace and at convenient times, reduced travel time and additional opportunities for reviewing course materials. Barak and Rafaeli (2004) say that students perceived web-based learning a tool that provides them with an opportunity for improvement of self-analysis and critical thinking as well as for sharing information with peers. The prominence of shrewd cell phones is developing quick (Iansiti \& Richards, 2006). These computerized gadgets speak to another age of innovative apparatuses that offer striking access to content, and open doors for imaginative utilize even by youthful kids (West, 2013)

Cell phones and tablets are among of the six new rising advances that may significantly affect instructing, learning, and research in necessary training (Chan, 2006). Particularly in the subject matter of mathematics, Ruthven and Hennessy (2002) made a comparison between the learning outcomes of computer-based teaching and mathematical thematic teaching. Compared to the traditional thematic teaching method, results showed that computer-assisted learning might significantly improve the advancement of scientific aptitudes and the development of a more profound perceptual ability for the pupils (Jonassen \& Grabowski, 2012; Jimoyiannis \& Komis, 2007).

Consequently, according to Bennett and Maton (2010), youthful youngsters can be depicted as advanced locals since they are experiencing childhood in the computerized world. The viability of an online intuitive mixed media learning apparatus versus message, content pictures, and sight and sound learning clarifications on math accomplishment, math self-adequacy, and understudy fulfillment (Means et al., 2009; Roschelle et al., 2000).

Intuitive sight and sound gathering understudies were happier with the strategy for learning revealed the method to be pleasant and additionally energizing and gave fair criticism. Online interactive multimedia learning is a realistic and creative method of teaching (Caplan \& Graham, 2004; Zhang et al., 2004). It is claimed that the use of manipulative not only increase students' conceptual understanding and problemsolving skills but also promotes their positive attitudes towards mathematics (Drent \& Meelissen, 2008; Feiman-Nemser, 2001). Pollara and Broussard (2011) conducted several studies to evaluate the mobile learning application and found it to be positive and indicated several benefits of using mobile devices for learning including an increase in achievement, productivity, engagement, and motivation.

Versatile advancements are assuming an inexorably critical part in understudies' scholastic lives. Gadgets, for example, cell phones, tablets, and digital book perusers associate clients with the world in a split second, increasing access to data and empowering intuitiveness with others. Applications that keep running on these gadgets let clients devour as well as find and deliver content. Accordingly, they keep on transforming how understudies learn and also impact their learning inclinations, both inside and outside the classroom.

With the above theories and literature, the use of mobile application was conceived to be appropriate for students to be utilized in teaching mathematics, as this would help students to become motivated learners and self-directed individuals.

\section{OBJECTIVES OF THE STUDY}

This study determined the effects of using a mobile application in teaching mathematics among Grade 8 students of a public national high school, Cebu City, Philippines. Accurately, it answered the: 1) Profile of the students concerning age, sex, and achievement in Grade 7 mathematics; 2) Students' achievement in mathematics significantly affect the corresponding pretest scores of the two groups; 3) Students' achievement in mathematics significantly affect the corresponding post-test scores of the two groups; and 4) Significant relationship between students' pretest and posttest scores of both groups.

\section{METHODOLOGY}

The researchers employed the quasi-experimental method of research using the pretest-posttest design. There were two groups in this study, the experimental group, and the control group. They correspond to the two sections of Grade 8 level, and the teacher was the researcher herself. The locale of the study is in a public national high school situated in Talamban, Cebu City, Philippines. The research subjects were the two sections of Grade 8 students of 40 per section. To make the two groups comparable, the subjects were given a standardized test as a pre-test. Scores were masterminded from most noteworthy to least, after which the mean normal and standard deviation were processed. The group classification was done using the tossing of a coin, where the head represents the control group and tail represents the experimental group. 
The standardized questionnaires on Linear Equations were downloaded from the Google free app at https://goo.gl/FQJsBW. It was conducted twice in both groups. The first set of standardized Linear Equation Questionnaires was given before the treatment was applied, this served their pre-test. Two months after the application of mobile app in addition to conventional teaching method, the second set of standardized test questionnaires was again conducted to both groups this time it served as their posttest.

In the identification of groups, the researchers tossed a coin in assigning the experimental and control groups randomly. The control group was exposed to the traditional method of teaching, while the experimental group to mobile application in addition to the conventional method of teaching mathematics. Both groups were given the same topic, finding the equation of a line, which covered ten teaching hours, excluding the pretest and posttest.

The control group was exposed to a purely lecture-discussion method using chalk and board. There were also some problem exercises, instructional materials but no electronic gadget of any kind was used. The experimental group was subjected to seven hours of lecture-discussion, three hours exposed to the mobile application. The three-hour exposure to the mobile application was interrupted once in a while for further discussion and emphasis of the lesson. It also includes the downloading and orientation on how to use this mobile application Since students in the experimental group were all technologically equipped with cellular phones/smartphones and were literate in manipulating these gadgets, only a few minutes was spent for such orientation. The researchers provided the students with exercises for them to work on using the downloaded application specifically the equation of a line. Every student in the experimental group was given an equal opportunity to demonstrate how to find the answer to the given exercise. The two groups underwent a pretest and a posttest where scores are statistically evaluated to determine the possible effects of using mobile app as an instructional tool in finding the equation of a line.

During enrollment, all incoming Grade 8 students were required to submit student's profile and Form 138 to the Guidance Office. The teacher handling the two sections is also controlled. The student's profile and average grade in Mathematics 7 were utilized to determine the subjects' profile regarding IQ, interest, and motivation. Before administering the experimental treatment, both groups were subjected to a pretest. The researchers checked the test papers and the scores were announced to the students. After three weeks, where the control group was subjected to the conventional method of teaching and the experimental group to the mobile application in addition to the conventional method, a posttest, which was precisely the same as the pretest, was given to both groups again. Likewise, the teacher researchers corrected the test papers, and the scores were collected for statistical treatment using frequency, simple percentage, mean, standard deviations, rank, and t-test were used to treat the gathered data.

\section{RESULTS AND DISCUSSIONS}

Table 1 presents the gathered data from the two groups. These data include their age, sex, and final grade in Math 7. 
Table 1. Profile of the Research Subjects

\begin{tabular}{|c|c|c|c|c|}
\hline & \multicolumn{4}{|c|}{ Groups } \\
\hline & \multicolumn{2}{|c|}{$\begin{array}{l}\text { Control } \\
(\mathrm{n}=40)\end{array}$} & \multicolumn{2}{|c|}{$\begin{array}{c}\text { Experimental } \\
(n=40)\end{array}$} \\
\hline & $\mathbf{f}$ & $\%$ & $\mathbf{f}$ & $\%$ \\
\hline \multicolumn{5}{|l|}{ A. Age (in years) } \\
\hline 12 & 2 & 5.00 & 0 & 0.00 \\
\hline 13 & 8 & 20.00 & 9 & 22.50 \\
\hline 14 & 25 & 62.50 & 23 & 57.50 \\
\hline 15 & 4 & 10.00 & 5 & 12.50 \\
\hline 16 & 0 & 0.00 & 1 & 2.50 \\
\hline 17 & 1 & 2.50 & 0 & 0.00 \\
\hline 18 & 0 & 0.00 & 2 & 5.00 \\
\hline Mean: & 13.875 & & 14.150 & \\
\hline StDev: & 0.853 & & 1.122 & \\
\hline \multicolumn{5}{|l|}{ B. Sex } \\
\hline Male & 15 & 37.50 & 16 & 40.00 \\
\hline Female & 25 & 62.50 & 24 & 60.00 \\
\hline \multicolumn{5}{|l|}{ C. Grade in Math 7} \\
\hline 95 - 100 (Excellent) & 2 & 5.00 & 1 & 2.50 \\
\hline 90 - 94 (Very Good) & 6 & 15.00 & 4 & 10.00 \\
\hline $80-89$ (Good) & 32 & 80.00 & 35 & 87.50 \\
\hline Mean: & 85.775 & & 85.800 & \\
\hline StDev: & 4.016 & & 3.824 & \\
\hline
\end{tabular}

The table shows that more than $50 \%$ of the students' age in both the control group and experimental group fell under the age of 14 years old. This is the right age of Grade 8 students, as mandated by the Department of Education (DepEd), the age entry for junior high school is 12 years old, and that they turn 13 years old during their Grade 7 level, but there were some of these students had just turned 12 years old before enrollment, their birthdays could be April or May. Students, whose age fell between 15 to18 years old, had been a repeater, or a dropout during their elementary education. From the above data, it can be implied that respondents in both groups were equivalent regarding age levels. Most of them were of the same age category which means respondents can be classified as teenagers.

Also, the table shows that there were 15 males and 25 females that belonged to the control group while there were 16 males and 24 females in the experimental group. The Philippine Statistics Authority in their 2013 survey revealed that there were more male children and youth who were out of school than female. The top reasons for not attending school are lack of personal interest and insufficient family income. Thus, the two groups were comparable concerning their gender.

Further, it revealed that majority of the respondents in both groups fell under the category Good, which grade ranges from 80 to 89 . This could mean that their mathematics background in their previous years was not so strong. Watts et al. (2014), found out that preschool mathematics ability predicts mathematics achievement through age 15 , even after accounting for early reading, cognitive skills, and family and child characteristics. Moreover, they found out that growth in mathematical ability between age 54 months and first grade is even stronger predictors of adolescent mathematical achievement. Furthermore, the table shows that most of the respondents were average as to analytical capabilities. It further implies that both groups were equivalent and comparable regarding their final grades in Mathematics 7.

Table 2 presents the results of Grade 8 mathematics of both groups. 
Table 2. Students' Achievement in Grade 8 Mathematics

\begin{tabular}{cccccccccc}
\hline & & \multicolumn{3}{c}{$\begin{array}{c}\text { Control Group } \\
(\mathbf{n}=\mathbf{4 0})\end{array}$} & \multicolumn{3}{c}{$\begin{array}{c}\text { Experimental Group } \\
(\mathbf{n}=\mathbf{4 0})\end{array}$} \\
\hline & & \multicolumn{2}{c}{ Pretest } & \multicolumn{2}{c}{ Posttest } & \multicolumn{2}{c}{ Pretest } & \multicolumn{2}{c}{ Posttest } \\
\hline Scores & Description & $\mathbf{f}$ & $\mathbf{0}$ & $\mathbf{f}$ & $\mathbf{\%}$ & $\mathbf{f}$ & $\mathbf{\%}$ & $\mathbf{f}$ & $\mathbf{\%}$ \\
\hline $32-40$ & Excellent & 0 & 0.00 & 23 & 57.50 & 0 & 0.00 & 21 & 52.50 \\
\hline $24-31$ & Very Proficient & 1 & 2.50 & 9 & 22.50 & 0 & 0.00 & 19 & 47.50 \\
\hline $16-23$ & Proficient & 9 & 22.50 & 8 & 20.00 & 7 & 17.50 & 0 & 0.00 \\
\hline $8-15$ & Less Proficient & 25 & 62.50 & 0 & 0.00 & 31 & 77.50 & 0 & 0.00 \\
\hline $0-7$ & Poor & 5 & 12.50 & 0 & 0.00 & 2 & 5.00 & 0 & 0.00 \\
\hline & Mean: & 12.450 & & 30.950 & & 12.450 & & 32.150 & \\
\hline & StDev: & 4.332 & & 6.168 & & 3.281 & & 3.704
\end{tabular}

Table 3. Significant Relationship Between Grade 8 Math and Pretest Scores

\begin{tabular}{lccccccc}
\hline Group & r & Strength & t-Value & df & Critical Value & Significance & Decision \\
\hline A. Control & & & & & & & \\
\hline Grade 8 Math & 0.203 & Weak & 1.228 & 38 & 2.024 & Not significant & Ho Accepted \\
\hline Pretest Scores & & & & & & & \\
\hline B. Experimental & & & & & & & \\
\hline Grade 8 Math & -0.078 & Little & -0.482 & 38 & 2.024 & Not significant & Ho Accepted \\
\hline Pretest Scores & & & & & & &
\end{tabular}

The table revealed that the pretest scores obtained by the respondents of both groups have an equal mean of 12.450 (very low). This implies that there is a need for improving their mathematical skills. More practice, drills, examples, assignments as well as board works were needed to help sharpen the analytical capabilities of the learners.

Furthermore, the table shows an increasing result of the posttest scores of both groups. It implies that there was an increase in learning among students of both groups. Based on the table, the control group got a mean score of 30.950 and a standard deviation of 6.168 in their posttest. Whereas, the experimental group got a mean score of 32.150 and a standard deviation of 3.704. Thus, it further connotes that the mobile application has contributed to an enhanced students learning.

According to Rossing et al. (2012), The developing utilization of versatile innovation on school grounds proposes the eventual fate of the classroom, including learning exercises, investigate, and even understudy workforce correspondences, will depend intensely on portable innovation. Park (2011) says that as mobile devices are becoming increasingly ubiquitous, many teachers have incorporated the technology into their teaching and learning environments.

Table 3 shows the test of the significant relationship of pretest scores of both groups.

The table shows the relationship between the Grade 8 mathematics and pretest scores of the two groups of students. Further, it presents that the mean average of the control group in their Grade 7 mathematics is 85.775 whereas for the experimental is 85.800 and the mean score in their pre-test is 12.450 for both groups. The data revealed that the grades of students in the mathematics of both groups have no significant differences from the results of their pretest scores.

The study of Midley et al. (1989) found that the rate of change within the school year in students' expectancies, perceived performance, and perceived task difficulty in mathematics, depending on teacher efficacy before and after the transition. Students who moved from high- to low-efficacy math teachers during the transition ended the junior high year with the lowest expectancies and perceived performance and the highest perceptions of task difficulty.

Table 4 shows the test of the significant relationship of posttest scores of both groups. 
Table 4. Significant Relationship Between Grade 8 Math and Posttest Scores

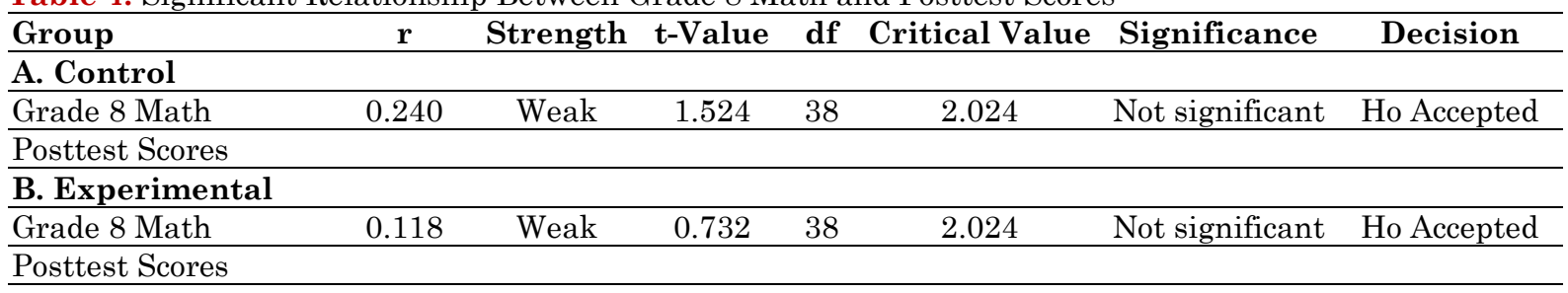

Table 5. Significant Relationship Between Pretest Scores and Posttest Scores

\begin{tabular}{|c|c|c|c|c|c|c|c|}
\hline Group & $\mathbf{r}$ & Strength & t-Value & df & Critical Value & Significance & Decision \\
\hline \multicolumn{8}{|l|}{ A. Control } \\
\hline Pretest Scores & 0.406 & Moderate & 2.739 & 38 & 2.024 & Significant & Ho Rejected \\
\hline \multicolumn{8}{|l|}{ Posttest Scores } \\
\hline \multicolumn{8}{|c|}{ B. Experimental } \\
\hline Pretest Scores & 0.140 & Weak & 0.872 & 38 & 2.024 & Not significant & Ho Accepted \\
\hline
\end{tabular}

Table 4 presents the relationship between Grade 8 Mathematics and posttest scores of both the control and experimental group. The table reveals that computed r-values have a weak positive relationship between the Grade 8 mathematics and their scores in the post-test. Also, it is revealed that both groups have no significant differences from the results of their posttest scores.

The study of Clark (2015) revealed the student participants responded favorably to the intervention and experienced an increase in their engagement when compared to the traditional classroom experience. Regarding academic performance, no significant changes were demonstrated between the intervention and those taught in a traditional classroom environment.

The study of Hill et al. (2005) explored whether and how teachers' mathematical knowledge for teaching contributes to gains in students' mathematics achievement. They found that the mathematical knowledge of teachers was significantly related to student achievement gains in both grades after controlling for the crucial student- and teacher-level covariates. As indicated by Fuchs et al. (2005) say that mentoring diminished the commonness of math incapacity, with pervasiveness and seriousness changing as a component of a recognizable proof technique and math area. Consideration represented extraordinary fluctuation in anticipating every part of end-of-year math execution.

Table 5 shows the test of the significant relationship of pretest and posttest scores of both groups.

The table reveals increasing results in their posttest for both groups. It further implies that there is an increase in learning among Grade 8 students. The results indicate the acceptance of the null hypothesis, which says that there is no significant difference between students pretest and post-test scores of the control group. The results indicated a significant improvement of the achievement of the experimental versus the control group. Students who used the games in their classrooms and school labs reported greater motivation compared to students who played the application only in the school labs. Prior knowledge in mathematics did not play significant roles in the achievement of the experimental group.

The findings of the study of Cheung and Slavin (2013) suggest that educational technology produced a positive, though small, effect. Kaloo and Mohan (2012) reveal that the students were able to improve their performance and they were excited about using a mobile device for learning. They adapted well to using this method of learning for the first time. The students who improved were those who had done algebra in a previous school term but may have been failing the subject. However, the application did not make a significant impact on students who were learning the algebraic content for the first time.

\section{CONCLUSIONS}

The study concluded that the use of the mobile application in teaching mathematics to Grade 8 students in a public national high school by using the mobile application had somehow helped enhanced students' achievement and learning. In line with the quality education, the administrator should enforce and include the use of the mobile application in carrying out learning to its maximum. The teacher must also equip with the latest trend for learners to become globally competitive. 


\section{RECOMMENDATIONS}

The researchers recommend that the: 1) DepEd must review the competencies to be covered in every grading period because there are competencies which are too many that teachers cannot satisfactorily tackle it with the learners; 2) School administrator should conduct surveys and use these to determine which topics are appropriate for professional development; 3) Subject coordinators must guide and assist teachers in the making of teaching tools and in the choice of teaching strategies that are appropriate for the kind of learners; 4) Teachers in mathematics should be sent to seminars, workshops, and conferences to update their teaching strategies in order to make them more innovative in making learning fruitful and enjoyable; and 5) Students must have regular access to technologies that support learning so as to advance their mathematical thinking, reasoning, problem-solving, and communication skills.

\section{Disclosure statement}

No potential conflict of interest was reported by the authors.

\section{Notes on contributors}

Jonathan O. Etcuban - Doctor of Philosophy in Technology Management, Doctor of Philosophy in Education Management, Faculty, College of Computer Studies, University of Cebu, Cebu City, Philippines.

Leocineza D. Pantinople - Master of Science in Teaching Mathematics, Faculty, Talamban National High School, Cebu City, Philippines.

\section{REFERENCES}

Ally, M. (Ed.). (2009). Mobile learning: Transforming the delivery of education and training. Athabasca University Press. Retrieved on February 2018 from https://goo.gl/YPWzzD

Angeli, C., \& Valanides, N. (2009). Epistemological and methodological issues for the conceptualization, development, and assessment of ICT-TPCK: Advances in technological pedagogical content knowledge (TPCK). Computers \& Education, 52(1), 154-168. https://doi.org/10.1016/j.compedu.2008.07.006

Barab, S. A., \& Plucker, J. A. (2002). Smart people or smart contexts? Cognition, ability, and talent development in an age of situated approaches to knowing and learning. Educational Psychologist, 37(3), 165-182. https://doi.org/10.1207/S15326985EP3703_3

Barak, M., \& Rafaeli, S. (2004). On-line question-posing and peer-assessment as means for web-based knowledge sharing in learning. International Journal of Human-Computer Studies, 61(1), 84-103. https://doi.org/10.1016/j.ijhes.2003.12.005

Bennett, S., \& Maton, K. (2010). Beyond the 'digital natives' debate: Towards a more nuanced understanding of students' technology experiences. Journal of computer assisted learning, 26(5), 321-331. https://doi.org/10.1111/j.1365-2729.2010.00360.x

Bonk, C. J., \& King, K. S. (2012). Searching for learner-centered, constructivist, and sociocultural components of collaborative educational learning tools. In Electronic collaborators (pp. 61-86). Routledge. Retrieved on February 2018 from https://goo.gl/9S4Ekr

Brown, D. (2006). Can instructional technology enhance the way we teach students and teachers? Journal of Computing in Higher Education, 17(2), 121. https://doi.org/10.1007/BF03032701

Caplan, D., \& Graham, R. (2004). The development of online courses. Theory and practice of online learning, 175. Retrieved on February 2018 from https://goo.gl/SA9D87

Caudill, J. G. (2007). The growth of m-learning and the growth of mobile computing: Parallel developments. The International Review of Research in Open and Distributed Learning, 8(2). https://doi.org/10.19173/irrodl.v8i2.348

Chan, T. W., Roschelle, J., Hsi, S., Kinshuk, Sharples, M., Brown, T., ... Soloway, E. (2006). One-to-one technology-enhanced learning: An opportunity for global research collaboration. Research and Practice in Technology Enhanced Learning, 1(01), 3-29. Retrieved on February 2018 from https://goo.gl/QytjVZ

Cheung, A. C., \& Slavin, R. E. (2013). The effectiveness of educational technology applications for enhancing mathematics achievement in K-12 classrooms: A meta-analysis. Educational research review, 9, 88-113. https://doi.org/10.1016/j.edurev.2013.01.001 
Clark, K. R. (2015). The effects of the flipped model of instruction on student engagement and performance in the secondary mathematics classroom. Journal of Educators Online, 12(1), 91-115. https://doi.org/10.9743/JEO.2015.1.5

Dede, C. (2008). Theoretical perspectives influencing the use of information technology in teaching and learning. In International handbook of information technology in primary and secondary education (pp. 43-62). Springer, Boston, MA. Retrieved on February 2018 from https://goo.gl/THchd4

Drent, M., \& Meelissen, M. (2008). Which factors obstruct or stimulate teacher educators to use ICT innovatively? Computers \& Education, 51(1), 187-199. https://doi.org/10.1016/j.compedu.2007.05.001

Etcuban, J. O. (2013). Automated test generator for the faculty of the University of Cebu, Philippines. IAMURE International Journal of Mathematics, Engineering \& Technology, 6, 30. Retrieved on January 2018 from https://goo.gl/4kXMWm

Feiman-Nemser, S. (2001). From preparation to practice: Designing a continuum to strengthen and sustain teaching. Retrieved on February 2018 from https://goo.gl/AWV6CP

Franklin, T., \& Peng, L. W. (2008). Mobile math: Math educators and students engage in mobile learning. Journal of computing in higher education, 20(2), 69-80. https://doi.org/10.1007/s12528-0089005-0

Fuchs, L. S., Compton, D. L., Fuchs, D., Paulsen, K., Bryant, J. D., \& Hamlett, C. L. (2005). The prevention, identification, and cognitive determinants of math difficulty. Journal of Educational Psychology, 97(3), 493. https://doi.org/10.1037/0022-0663.97.3.493

Hill, H. C., Rowan, B., \& Ball, D. L. (2005). Effects of teachers' mathematical knowledge for teaching on student achievement. American educational research journal, 42(2), 371-406. https://doi.org/10.3102/00028312042002371

Hmelo-Silver, C. E. (2004). Problem-based learning: What and how do students learn? Educational psychology review, 16(3), 235-266. https://doi.org/10.1023/B:EDPR.0000034022.16470.f3

Hromek, R., \& Roffey, S. (2009). Promoting Social and Emotional Learning with Games: "It's Fun and We Learn Things". Simulation \& Gaming, 40(5), 626-644. https://doi.org/10.1177/1046878109333793

Iansiti, M., \& Richards, G. L. (2006). The information technology ecosystem: Structure, health, and performance. The Antitrust Bulletin, 51(1), 77-110. Retrieved on February 2018 from https://goo.gl/m96M7p

Jimoyiannis, A., \& Komis, V. (2007). Examining teachers' beliefs about ICT in education: Implications of a teacher preparation programme. Teacher 149-173. https://doi.org/10.1080/13664530701414779

Johnson, L., Becker, S. A., Cummins, M., Estrada, V., Freeman, A., \& Hall, C. (2016). NMC horizon report: 2016 higher education edition (pp. 1-50). The New Media Consortium. Retrieved on February 2018 from https://goo.gl/8jWy4r

Jonassen, D. H., \& Grabowski, B. L. (2012). Handbook of individual differences, learning, and instruction. Routledge. Retrieved on February 2018 from https://goo.gl/GTYbZY

Kalloo, V., \& Mohan, P. (2012). MobileMath: An innovative solution to the problem of poor Mathematics performance in the Caribbean. The Caribbean Teaching Scholar, 2(1). Retrieved on February 2018 from https://goo.gl/v9UDuM

Kebritchi, M., Hirumi, A., \& Bai, H. (2010). The effects of modern mathematics computer games on mathematics achievement and class motivation. Computers \& Education, 55(2), 427-443. https://doi.org/10.1016/j.compedu.2010.02.007

Khaddage, F., Lattemann, C., \& Bray, E. (2011). Mobile apps integration for teaching and learning. (Are Teachers Ready to Re-blend?). In Society for Information Technology \& Teacher Education International Conference (pp. 2545-2552). Association for the Advancement of Computing in Education (AACE). Retrieved on January 2018 from https://goo.gl/Vek2vo

Kritzenberger, H. (2004). Architectures for constructive multimedia learning environments: challenges for narrative teaching models. In EdMedia: World Conference on Educational Media and Technology (pp. 88-95). Association for the Advancement of Computing in Education (AACE). Retrieved on February 2018 from https://goo.gl/GHEUAm 
McNeese, M. D., Theodorou, E., Ferzandi, L., Jefferson Jr, T., \& Ge Jr, X. (2002). Distributed cognition in shared information spaces. In Proceedings of the Human Factors and Ergonomics Society Annual Meeting (Vol. 46, No. 3, pp. 556-560). Sage CA: Los Angeles, CA: SAGE Publications. Retrieved on February 2018 from https://goo.g1/jHHqAL

Means, B., Toyama, Y., Murphy, R., Bakia, M., \& Jones, K. (2009). Evaluation of evidence-based practices in online learning: A meta-analysis and review of online learning studies. Retrieved on February 2018 from http://repository.alt.ac.uk/629/

Midgley, C., Feldlaufer, H., \& Eccles, J. S. (1989). Change in teacher efficacy and student self-and task-related beliefs in mathematics during the transition to junior high school. Journal of Educational Psychology, 81(2), 247. https://doi.org/10.1037/0022-0663.81.2.247

Mouza, C., \& Barrett-Greenly, T. (2015). Bridging the app gap: An examination of a professional development initiative on mobile learning in urban schools. Computers \& Education, 88, 1-14. https://doi.org/10.1016/j.compedu.2015.04.009

Naismith, L., Lonsdale, P., Vavoula, G. N., \& Sharples, M. (2004). Mobile technologies and learning. Retrieved on February 2018 from https://goo.gl/L3CB6F

Niess, M. L. (2005). Preparing teachers to teach science and mathematics with technology: Developing a technology pedagogical content knowledge. Teaching and teacher education, 21(5), 509-523. https://doi.org/10.1016/j.tate.2005.03.006

Park, Y. (2011). A pedagogical framework for mobile learning: Categorizing educational applications of mobile technologies into four types. The International Review of Research in Open and Distributed Learning, 12(2), 78-102. https://doi.org/10.19173/irrodl.v12i2.791

Phillips, M. M., Koehler, M. J., Zhang, G., Yadav, A., \& Rosaen, C. (2005). Results of an experiment evaluating the use of video cases to help pre-service teachers become better teachers of literacy. In EdMedia: World Conference on Educational Media and Technology (pp. 585-592). Association for the Advancement of Computing in Education (AACE). Retrieved on February 2018 from https://goo.gl/ijXaKJ

Pollara, P., \& Broussard, K. K. (2011). Mobile technology and student learning: What does current research reveal? International Journal of Mobile and Blended Learning (IJMBL), 3(3), 34-42. https://doi.org/10.4018/jmbl.2011070103

Prahalad, C. K., \& Ramaswamy, V. (2003). The new frontier of experience innovation. MIT Sloan management review, 44(4), 12. Retrieved on February 2018 from https://goo.gl/gQe7Cy

Proserpio, L., \& Gioia, D. A. (2007). Teaching the virtual generation. Academy of Management Learning \& Education, 6(1), 69-80. https://doi.org/10.5465/amle.2007.24401703

Roschelle, J. M., Pea, R. D., Hoadley, C. M., Gordin, D. N., \& Means, B. M. (2000). Changing how and what children learn in school with computer-based technologies. The future of children, 76-101. https://doi.org/10.2307/1602690

Rosen, L. D. (2010). Rewired: Understanding the iGeneration and the way they learn. St. Martin's Press. Retrieved on February 2018 from https://goo.gl/PHXUe7

Rossing, J. P., Miller, W., Cecil, A. K., \& Stamper, S. E. (2012). iLearning: The future of higher education? Student perceptions of learning with mobile tablets. Retrieved on March 2018 from https://goo.gl/TjGsg9

Ruthven, K., \& Hennessy, S. (2002). A practitioner model of the use of computer-based tools and resources to support mathematics teaching and learning. Educational studies in mathematics, 49(1), 47-88. https://doi.org/10.1023/A:1016052130572

Sadik, A. (2008). Digital storytelling: A meaningful technology-integrated approach for engaged student learning. Educational technology research and development, 56(4), 487-506. https://doi.org/10.1007/s11423-008-9091-8

Sha, L., Looi, C. K., Chen, W., \& Zhang, B. H. (2012). Understanding mobile learning from the perspective of self-regulated learning. Journal of Computer Assisted Learning, 28(4), 366-378. https://doi.org/10.1111/j.1365-2729.2011.00461.x

Shyu, H. Y. C. (2000). Using video-based anchored instruction to enhance learning: Taiwan's experience. British Journal of Educational Technology, 31(1), 57-69. https://doi.org/10.1111/14678535.00135 
Stein, M. K., Engle, R. A., Smith, M. S., \& Hughes, E. K. (2008). Orchestrating productive mathematical discussions: Five practices for helping teachers move beyond the show and tell. Mathematical thinking and learning, 10(4), 313-340. https://doi.org/10.1080/10986060802229675

Stigler, J. W., \& Hiebert, J. (2009). The teaching gap: Best ideas from the world's teachers for improving education in the classroom. Simon and Schuster. Retrieved on January 2018 from https://goo.gl/Z7zYT2

Sung, Y. T., Chang, K. E., \& Liu, T. C. (2016). The effects of integrating mobile devices with teaching and learning on students' learning performance: A meta-analysis and research synthesis. Computers \& Education, 94, 252-275. https://doi.org/10.1016/j.compedu.2015.11.008

Tan, H. S. (2003). The use of a virtual environment in the education of engineering students (Doctoral dissertation, Durham University). Retrieved on February 2018 from http://etheses.dur.ac.uk/3150/

Watts, T. W., Duncan, G. J., Siegler, R. S., \& Davis-Kean, P. E. (2014). What's past is prologue: Relations between early mathematics knowledge and high school achievement. Educational Researcher, 43(7), 352-360. https://doi.org/10.3102/0013189X14553660

West, D. M. (2013). Mobile learning: Transforming education, engaging students, and improving outcomes. Brookings Policy Report, 1-7. Retrieved on February 2018 from https://goo.gl/uQxCyu

Zhang, D., Zhao, J. L., Zhou, L., \& Nunamaker Jr, J. F. (2004). Can e-learning replace classroom learning? Communications of the ACM, 47(5), 75-79. https://doi.org/10.1145/986213.986216

Zhao, C. M., \& Kuh, G. D. (2004). Adding value: Learning communities and student engagement. Research in higher education, 45(2), 115-138. https://doi.org/10.1023/B:RIHE.0000015692.88534.de 